\title{
FINANCING OF MUNICIPAL INVESTMENT WITHIN SUSTAINABLE DEVELOPMENT FRAMEWORK
}

\author{
MAGDALENA KOGUT-JAWORSKA, ${ }^{1}$ AGNIESZKA JACHOWICZ, \\ JOLANTA ZAWORA ${ }^{3}$ \\ ${ }^{1}$ University of Szczecin, Faculty of Management and Economics of Services, POLAND \\ e-mail: magdalena.kogut@wzieu.pl \\ ${ }^{2}$ University of Dabrowa Gornicza, Faculty of Management, POLAND \\ e-mail: jahowicza@interia.pl \\ ${ }^{3}$ University of Rzeszow, Faculty of Economics, POLAND \\ e-mail: jolazawora@gmail.com
}

RECEIVED
ACCEPTED
JEL
CLASSIFICATION

KEYWORDS

ABSTRACT
10 December 2018

28 December 2018

$\mathrm{F} 42, \mathrm{~F} 63, \mathrm{H} 41, \mathrm{H} 87$

public finance, self-government unit, sustainable development

The current policies of the territorial self-government ought to take into consideration challenges resulting from constantly changing global development processes. Adoption of modern assumptions and their consequent implementation is a pre-condition for development of the territorial self-government at the local level. It also gives ground for assumptions that implementation of the objectives set at the national or the EU levels will be successful. There is also a chance that the realization of sustainable development objectives will be getting more acceptance from the society. The concept of the sustainable development, comprising the natural environment and its resources, economic cooperation, and reinforcing social ties, is the best way to make use of the development potential. The aim of the paper is to stress the importance of development planning at the local level and to assess possibilities for communal investment in the context of sustainable development implementation. The objective of the paper is also to assess opportunities of capital raising for investment in local communities, which has a large impact on the living standard of the population. The analysis includes the scope and main directions of the self-governmental investment. The time frame covers the 2010-2016 period. The empiric material has been supplied by The Bank for Local Data of the Central Statistical Office (the "GUS") and from analyses made by the Ministry of Finance.

\section{Sustainable development - from world to terpitopial approach}

In 1987, the Bruntland Commission published its report: "Our Common Future", in an effort to link the issues of economic development and environmental stability. In doing so, this report provided the oft - cited definition of sustainable development as "development that meets the needs of the present without compromising the ability of future generations to meet their own needs" (United Nations General Assembly, 1987, p. 43). Albeit somewhat 
vague, this concept of sustainable development aims to maintain economic advancement and progress while protecting the long-term value of the environment; it "provides a framework for the integration of environment policies and development strategies" (United Nations General Assembly, 1987).

At the EU level, an important role in the implementation of sustainable development is played by the Strategy for Sustainable Development of the European Union, approved in May 2001 by the European Council in Gothenburg, and then renewed in June 2006 (Council of the European Union, 2006). It specifies the desired directions of social, economic and environmental changes in the long term, as well as how to achieve them.

Sustainable development occurs one of the most important challenges of the modern world, perceived also as a key trend of global environmental policy and socio-economic development (Famielec, 2009, pp. 39-41; European Union, 2013, p. 30).

The broad definition, proposed by the Brundtland Commission, does not limit the scope of sustainability. The explanation does, however, touch on the importance of intergenerational equity. This concept of conserving resources for future generations is one of the major features that distinguish sustainable development policy from traditional environmental policy, which also seeks to internalize the externalities of environmental degradation. The overall goal of sustainable development (SD) is the long-term stability of the economy and environment; this is only achievable through the integration and acknowledgement of economic, environmental, and social concerns throughout the decision making process.

The key principle of sustainable development underlying all others is the integration of environmental, social, and economic concerns into all aspects of decision making. All other principles in the SD framework have integrated decision making at their core (Dernbach, 2003; Stoddart, 2011). It is this deeply fixed concept of integration that distinguishes sustainability from other forms of policy.

The overarching objective of sustainable development is to integrate economic, social and environmental policies at the local, regional and global levels (Ministerstwo Środowiska, 1999, pp. 15-17; Fiedor, 2013, pp. 10-11; Ghosh, Goswami, 2014). Implementation of sustainable development is related to a fundamental change in how to proceed, taking into account the integrated interdisciplinary approach (Urbaniec, Halavach, 2008; Borys, 2011, pp. 75-81).

All the 17 Sustainable Development Goals (SDGs) are very comprehensive in their scope and cover all policy domains that are critical for sustainable growth and development. They are also strongly interconnected (meaning that progress in one area generates positive spillovers in other domains) and require both coherence in policy design and implementation, and multi-stakeholder engagement to reach standards in a shared responsibilities across multiple actors. The implementation of SDGs should therefore be considered in a systemic way and rely on a whole-of-society approach for citizens to fully reap expected benefits.

Cities and regions have a crucial role to play in SDGs achievements although the 2030 Agenda was not designed specifically for or by them. Indeed, most underlying policies and investments are a shared responsibility across levels of government and it is estimated that $65 \%$ of the 169 targets underlying the 17 SDGs will not be reached without proper engagement of and coordination with local and regional governments (UN..., 2016). For example, subnational governments were responsible for $59.3 \%$ of total public investment in 2015 throughout the OECD area and for almost $40 \%$ worldwide; most of such investments related to infrastructure for basic services over which cities and/or regions have core competencies and which are sometimes the subject of dedicated SDGs 
(e.g. education, health, social infrastructure, drinking water, sanitation, solid waste management, transports, and housing).

This is why there is the need to support interested cities and regions in "localising" the SDGs, meaning tailoring them to place-based contexts, understanding how they translate in their territorial specificities and realities, measuring distance from national average and peer cities or regions, and providing tailored guidance to mainstream the SDG lens into territorial planning, strategy setting and policy making. It is expected that the outcomes of the project can help cities and regions "(re)think" their approach to sustainability and well-being at the scale that matters the most.

A territorial approach to SDGs can also support the allocation and targeting of resources (fiscal, human, technical/infrastructure, etc.) to the most vulnerable groups and/or lagging regions. It can help improve the participation of local and regional authorities, as well as of grassroots communities for greater accountability and outcomes in the achievement of SDGs (OECD, 2017).

\section{Specilics of municipal investment and its importance for stimulating local development}

Municipal investments are one of the most important elements of the local development, which influence local competitiveness, improve communal and social services and enhance the local standard of living. Realization of municipal investment results in an increase of municipal property, lifting of the service level (in both, qualitative and quantitative aspects), as well as it creates favorable conditions for new business and residential locations. Regardless a variety of interpretations, the major goal of the local community investment remains to be gradual improvement of living standards of the local population and meeting the public needs (Sadowska, 2017, p. 139; Sadowska, Starosta-Grala, Ankudo-Jankowska, 2017, p. 41-51). Local community investments become this way an instrument of influencing the local socio-economic development and securing the proper treatment of the natural environment.

The common feature of all self-governmental investments is a necessity to engage some capital, usually for a relatively long period, which brings about uncertainty and financial risk for the ventures undertaken. Municipal investment is perceived as ; technical instruments for stimulating sustainable development ("integrated order"). Additionally, the realization of the goals has impact on the overall improvement of the natural environment ("ecological order") and on the standard of living of the population ("social order"), and at the same time on economic development of the community ("economic order") (Szaja, 2011, pp. 100-107).

Decisions made by local authorities about implementation of numerous investments are vital for the evolving position of the self-government - from the traditional administrative role, up to the the modern creative subject in its area of activity. For self-government authorities that are responsible for the local development, the investment is the most eligible way for capital allocation because of obvious future benefits, i.a.: in creation of new jobs. Municipal investment does not only benefit the investing entity, but it has positive influence on the neighbouring communities, as well as on the whole regions. The above results in bringing various measurable benefits, such as inflow of new technologies, reduced unemployment, benefits of scale, more effective allocation of resources, etc. 


\section{Assessment of financial capabilities for investment in local communities in the context of sustainable development}

Sustainable development and the local community level is conditioned by external factors, regional, national and the European Union policies, as well as by internal factors (natural, economic and human resources and effectiveness of their application). Authorities of the three above mentioned administration levels should aim at maintaining the well balanced and sustainable development for the present generation, having also in mind creation of similar opportunities for future generations (Korenik, 2011, p. 74-75). One of the main assumptions for sustainable local development is improvement of living standards in a particular area, achieved with the application of various tools and actions by local authorities which are able to maintain the necessary proportions within economic, social and environmental dimensions.

Development opportunities of local communities depend largely on investment, especially in infrastructure which has a direct impact on the living standards, improvement of natural environment as well as on conditions for investment. Underinvestment in the socio-economic infrastructure can be a major hindrance for development. Moreover, effective development policies are conditioned by availability of financial resources, so present day selfgovernments meet the challenge of fundraising for realization of investment projects which will determine their further development. Limited financing can make a considerable obstacle for implementation of the sustainable development concept at the local level.

One of the basic factors influencing current and investment decision is the revenue per capita which mirrors the development potential of the individual entity. Taking into consideration particular types of local communities, there can be noticed a strong differentiation of the revenue potential according to character of the area, being either city or rural. Towns based on the county statute feature the highest total and per capita income rates (Table 1). On the other hand, rural communities and those of the mixed city/rural character) feature relatively low income potential.

Table 1. Total revenues and revenues per capita - according to the community type in 2010 and in 2016 (PLN)

\begin{tabular}{lcccc}
\hline \multicolumn{1}{c}{ Type of income } & City borough & $\begin{array}{c}\text { Towns based on county } \\
\text { statute }\end{array}$ & $\begin{array}{c}\text { Mixed character borough } \\
\text { (rural/city) }\end{array}$ & Rural borough \\
\hline & \multicolumn{4}{c}{2010} \\
\hline Total income per capita & $2,654.4$ & $4,264.6$ & $2,733.3$ & $2,922.2$ \\
Own income per capita & $1,560.5$ & $2,713.3$ & $1,270.9$ & $1,048.1$ \\
\hline & \multicolumn{5}{c}{$3,8996.0$} & $4,058.8$ \\
\hline Total income per capita & $3,803.0$ & $5,899.9$ & $1,779.5$ & $1,532.7$ \\
Own income per capita & $2,098.7$ & $3,636.4$ & & \\
\hline
\end{tabular}

Source: own compilation based on the Central Statistical Office (2018).

Revenue potential of the Polish local communities shows strong regional differentiation. The weakest revenue potential appeared in the local communities of Opolskie region, where the local community revenue in 2016 accounted for only $83 \%$ of the national average. The richest were the local communities of Mazowieckie region, where the 
average per capita income (PLN 5,700) accounted for 124\% of the national average (PLN 3,823). Own income of local communities shows even larger disproportions according to the region. The lowest own income appeared in the communities of Podkarpackie region (64\% of the national average). The highest financial independence featured the local communities of Mazowieckie region - PLN 3,460, which made 146 of the national average. High own revenue potential characterized the communities of Dolnośląskie (Lower Silesia) and Zachodniopomorskie (Western Pomerania) regions.

Table 2. Per capita income in all regions compared to the national average in 2010 and 2016 (\%)

\begin{tabular}{lrrr}
\hline \multirow{2}{*}{ Regions (voivodship) } & \multicolumn{2}{c}{ Total per capita income } & Own per capita income \\
\cline { 2 - 4 } & 2010 & 2016 & 2010 \\
\hline Polska & 100.0 & 100.0 & 100.0 \\
\hline Dolnoślaskie & 103.2 & 100.2 & 119.7 \\
Kujawsko-Pomorskie & 93.8 & 97.3 & 87.2 \\
Lubelskie & 88.0 & 88.6 & 60.6 \\
Lubuskie & 91.6 & 91.7 & 81.4 \\
Lódzkie & 92.6 & 97.4 & 93.2 \\
Małopolskie & 99.3 & 97.3 & 86.3 \\
Mazowieckie & 122.7 & 124.3 & 150.4 \\
Opolskie & 87.1 & 83.4 & 82.5 \\
Podkarpackie & 95.1 & 87.5 & 62.6 \\
Podlaskie & 97.4 & 94.0 & 76.1 \\
Pomorskie & 107.9 & 107.4 & 113.3 \\
Śląskie & 100.1 & 98.0 & 112.5 \\
Świętokrzyskie & 97.3 & 87.2 & 72.3 \\
Warmińsko-Mazurskie & 94.1 & 94.6 & 76.6 \\
Wielkopolskie & 91.8 & 95.9 & 95.6 \\
Zachodniopomorskie & 93.7 & 102.1 & 97.4 \\
\hline
\end{tabular}

Local communities together with towns with country statute

Source: own compilation based on the Central Statistical Office (2018).

Operational surplus is a particularly important category when assessing financial capacity for investment made by local communities. The surplus mirrors the scope of investment and the cost, but also the commune's investment potential and credit rating. The capability to invest differed according to geographic location, with Eastern regions having below average capabilities, (see Table 3). The administrative units with the lowest ration included the communities of Warmińsko-Mazurskie, Lubelskie and Świętokrzyskie. It needs to be noted that in the period analysed (2010-2016), the size of the operational surplus mirrored the level of the local community investment. The correlation was noticeable at the both, regional and local community levels. The drop of investment by the local communities was particularly visible in 2016. 
Table 3. Operational result and investment expenditure in regions in 2010 and $2016(\%)$

\begin{tabular}{|c|c|c|c|c|c|}
\hline \multirow[t]{2}{*}{ Region (voivodship) } & \multicolumn{3}{|c|}{$\begin{array}{c}\text { Operational surplus in relation } \\
\text { to total income }\end{array}$} & \multicolumn{2}{|c|}{$\begin{array}{l}\text { Investment expenditure } \\
\text { in relation to total expenditure }\end{array}$} \\
\hline & 2010 & 2013 & 2016 & 2010 & 2013 \\
\hline Polska & 5.7 & 8.0 & 9.4 & 23.4 & 16.8 \\
\hline Dolnośląskie & 3.7 & 8.3 & 8.5 & 24.3 & 16.4 \\
\hline Kujawsko-Pomorskie & 5.8 & 8.2 & 9.6 & 21.8 & 18.4 \\
\hline Lubelskie & 3.4 & 7.0 & 7.8 & 22.9 & 18.3 \\
\hline Lubuskie & 2.4 & 6.7 & 8.9 & 26.5 & 11.7 \\
\hline Łódzkie & 5.8 & 7.7 & 9.3 & 22.0 & 18.4 \\
\hline Małopolskie & 6.3 & 8.5 & 8.5 & 21.2 & 14.9 \\
\hline Mazowieckie & 6.2 & 8.4 & 10.0 & 22.5 & 15.9 \\
\hline Opolskie & 4.0 & 7.4 & 7.6 & 22.2 & 13.6 \\
\hline Podkarpackie & 4.5 & 6.9 & 8.9 & 23.8 & 18.0 \\
\hline Podlaskie & 5.7 & 8.4 & 10.5 & 29.9 & 18.6 \\
\hline Pomorskie & 7.4 & 7.5 & 10.1 & 25.3 & 19.6 \\
\hline Śląskie & 7.4 & 7.5 & 9.1 & 21.6 & 18.8 \\
\hline Świętokrzyskie & 4.4 & 8.2 & 8.5 & 26.7 & 16.5 \\
\hline Warmińsko-Mazurskie & 2.8 & 6.4 & 8.6 & 26.4 & 14.5 \\
\hline Wielkopolskie & 7.2 & 9.5 & 11.7 & 23.9 & 15.1 \\
\hline Zachodniopomorskie & 5.8 & 7.8 & 9.5 & 22.4 & 16.8 \\
\hline
\end{tabular}

Local communities together with towns with country statute.

Source: own compilation based on the Central Statistical Office (2018).

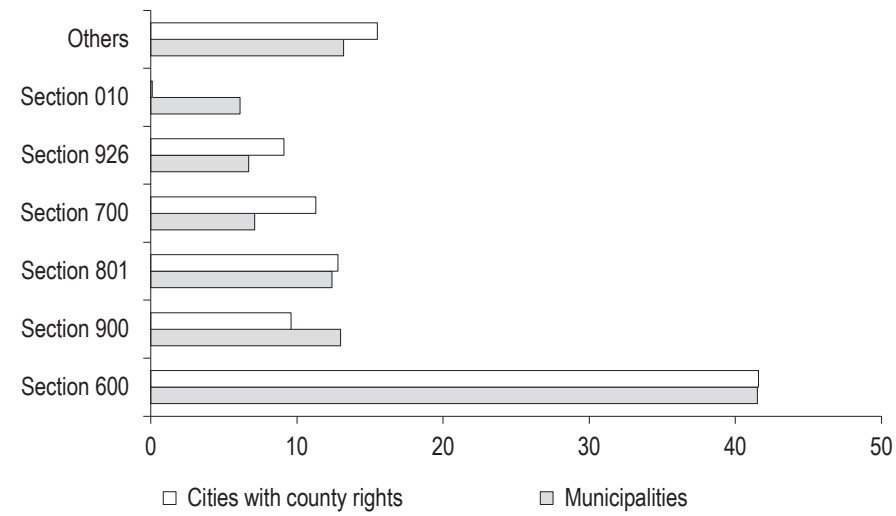

Section 600 - Transportation and Communications, Section 801 - Education, Section 900 - Utilities and Environment Protection, Section 700 - Housing, Section 926 - Physical Education, Section 010 - Agriculture.

Figure 1. Structure of investment expenditure of local communities and towns with county statute in some chosen sections in $2016(\%)$

Source: own compilation based on: GUS (2017), appendix B3, tables: 5 and 15. 
Most resources were applied by communes and towns with county statute into development of transport infrastructure $-41.5 \%$ of all investment expenditure, $13 \%$ of the expenditure covered the needs connected with utilities and natural environment protection. Investments on education and housing were also ranked high among all items. All the above priorities make important fields for investment and support the local economic activity, at the same time upgrading the living standards of the population and the chances for sustainable development.

\section{Conclusions}

Conditions for a sustainable local development can be assessed basing on capability of financing the development activity of local communities. Important factors which make limitations for the sustainable development include inadequate and territorially diversified revenues of local communities, and also their own low income potential. The drop in the value of local community investment in realization is particularly worrisome. The main directions of the self-governmental investment include major assumptions for the sustainable development of the local communities. They are, nonetheless, determined by the local socio-economic needs and on the other hand, by financial capability of the entities in question.

It needs to be indicated that the investment activity of local communities based on the assumptions for sustainable development should follow well planned actions of local authorities. Taking investment activities concentrated on achieving realistic goals can bring more benefit than chaotic, ad hoc actions. Concentration of actions and resources on well selected areas should contribute into reaching cohesive goals in the areas of economy, social development and ecology, thus implementing the concept of the sustainable development.

Conditions for the development in Poland are regulated by international agreements which outline the way for implementation of sustainable development. Besides, the model for such development is more and more accommodated into regional and local strategies. Local communities implement incrementally these strategies into their investment activities. It is expected that the above trends will be continued in the oncoming years.

\section{References}

Borys, T. (2011). Zrównoważony rozwój - jak rozpoznać ład zintegrowany. Problemy Ekorozwoju - Problems of Sustainable Development, 6 (2), 75-81.

Central Statistical Office (2018). Bank of Local Data information. Retrieved from: www.stat.gov.pl/bdl.

Council of the European Union (2006). Renewed EU Sustainable Development Strategy, 10917/06. Brussels.

Dernbach, J.C. (2003). Achieving sustainable development: The Centrality and multiple facets of integrated decision making. Indiana Journal of Global Legal Studies, 10, 247-285.

European Union (2013). Sustainable development in the European Union. 2013 monitoring report of the EU sustainable development strategy. Luxembourg.

Famielec, J. (2009). Wpływ idei zrównoważonego rozwoju na politykę państwa i funkcjonowanie przedsiębiorstw. In: B. Poskrobko (ed.), Wpływ idei zrównoważonego rozwoju na politykę państwa i regionów. Tom l: Problemy ogólnopaństwowe i sektorowe (pp. 36-48). Białystok: Wydawnictwo Wyższej Szkoły Ekonomicznej w Białymstoku.

Fiedor, B. (2013). Normatywny charakter koncepcji trwałego rozwoju a potrzeba poszukiwania jej podstaw mikroekonomicznych. Handel Wewnętrzny, 6A (t. 1), 7-20.

Ghosh, N., Goswami, A. (2014). Sustainability Science for Social, Economic, and Environmental Development. Hershey. PA: IGI Global. DOI: 10.4018/978-1-4666-4995-8.

GUS (2017). Gospodarka finansowa jednostek samorządu terytorialnego 2016. Warszawa. 
Korenik, S. (2011). Region ekonomiczny w nowych realiach społeczno-gospodarczych. Warszawa: CeDeWu.

Ministerstwo Środowiska (1999). Strategia Zrównoważonego Rozwoju Polski do 2025 roku. Retrieved from: www.access.zgwrp.org.pl/ materialy/ dokumenty/StrategiaZrownowazonegoRozwojuPolski/index1.html.

OECD (2017). A Territorial Approach to the Sustainable Development Goals: A role for Cities and Regions to leave no-one behind. 38th Meeting of the Regional Development Policy Committee 7-8 December 2017.

Sadowska, B. (2017). Rola rachunkowości we wspieraniu zrównoważonego rozwoju na przykładzie państwowego Gospodarstwa Leśnego Lasy Państwowe. Prace Naukowe Uniwersytetu Ekonomicznego we Wrocławiu, 479, 137-147.

Sadowska, B., Starosta-Grala, M., Ankudo-Jankowska, A. (2017). Sustainable development as a research area in economy. World Scientific News, 72, 41-51.

Stoddart, H. (2011). A Pocket guide to sustainable development governance. Stakeholder Forum.

Szaja, M. (2011). Polityka inwestycyjna ważnym instrumentem determinującym konkurencyjność i rozwój gminy. Studia Ekonomiczne i Regionalne, 4 (2), 100-107.

UN Sustainable Development Solution Network (2016). Getting Started with the SDGs in Cities. A Guide for Stakeholders. Retrieved from: http://unsdsn.org/wp-content/uploads/2016/07/9.1.8.-Cities SDG-Guide.

United Nations General Assembly. (1987). Report of the world commission on environment and development: Our common future. Oslo, Norway: United Nations General Assembly, Development and International Co-operation: Environment.

Urbaniec, M., Halavach, E. (2008). Wdrażanie rozwoju zrównoważonego: strategie i instrumenty. Częstochowa: Educator.

Cite this article aS: Kogut-Jaworska, M., Jachowicz, A., Zawora, J. (2018). Financing of municipal investment within sustainable development framework. European Journal of Service Management, 4 (28/2), 207-214. DOI: 10.18276/ejsm.2018.28/2-26. 